Images in...

\title{
Multi-modality imaging for accurate diagnosis of lipomatous hypertrophy of interatrial septum in a patient with lung cancer and increased FDG uptake on PET
}

\author{
Abhishek Chandrakant Sawant, ${ }^{1}$ Sanjay S Srivatsa² \\ 1Department of Internal Medicine, Community Regional Medical Center, Fresno, California, USA; \\ ${ }^{2}$ Division of Cardiology, Community Regional Medical Center, Fresno, California, USA
}

Correspondence to Dr Abhishek Chandrakant Sawant, acsawant@buffalo.edu

\section{DESCRIPTION}

A 66-year-old female with squamous cell carcinoma of lung underwent positron emission tomography (PET) scan for staging when increased fluorodeoxyglucose (FDG) uptake was noted in between the atrial septum concerning for possible metastasis (figure 1). CT chest revealed an interatrial mass where the Hounsfield density numbers were -50 to $-80 \mathrm{HU}$ 's and consistent with a fatty tumour (figure 2) without obliteration of fossa ovalis or tumour invasion via pulmonary veins to suggest a malignancy. A transoesophageal echocardiography (TEE) was performed which revealed a $3.3 \times 3.1 \mathrm{~cm}$ echo lucent mass markedly increasing the thickness of the atrial septum with sparing of the fossa ovalis and creating a 'dumbbell' appearance in the superior part of the interatrial septum (figure 3), consistent with lipomatous hypertrophy of interatrial septum (LHIS). LHIS has been shown to cause EKG changes, atrial arrhythmias, recurrent pericardial effusions and rarely sudden cardiac death. ${ }^{1}$ The increased FDG uptake on PET scan is believed to occur due to presence of brown fat in LHIS, ${ }^{2}$ resulting in a false interpretation of malignancy particularly with coexistent primary lung carcinoma. The specific CT appearance of fat in combination with the characteristic thickening of the atrial septum on TEE helped confirm the diagnosis. ${ }^{3}$ Thus in this case multi-modality imaging techniques were required to confirm the diagnosis of LHIS, prevent misdiagnosis of cancer recurrence and avoid unnecessary invasive procedures.

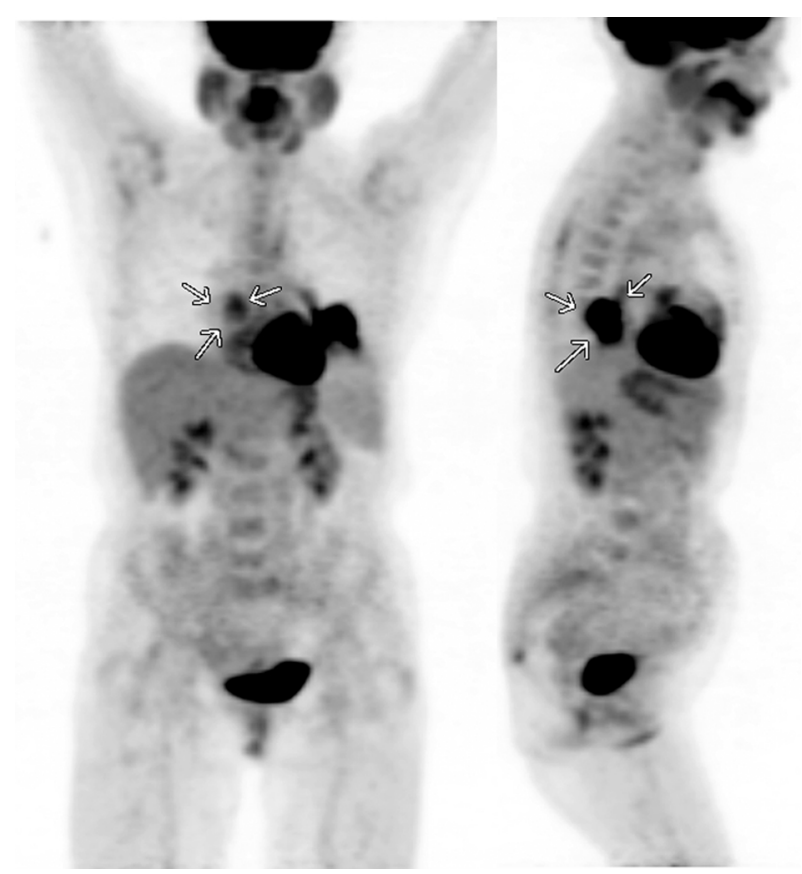

Figure 1 Antero-posterior (left) and lateral (right) views of positron emission tomography scan showing increased fluorodeoxyglucose uptake (white arrows) by lipomatous hypertrophy of interatrial septum.

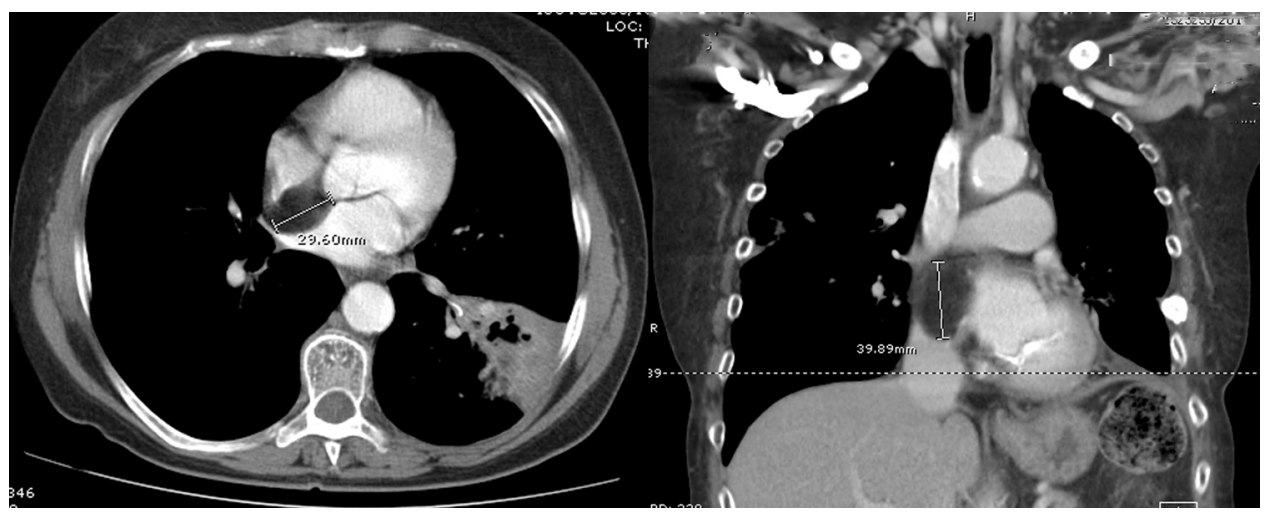

Figure 2 Axial (left) and coronal (right) views of CT chest showing lipomatous hypertrophy of interatrial septum with same Hounsfield units $(-50$ to $-80 \mathrm{HU}$ 's) as that of fatty tissue. 


\section{BMJ Case Reports}

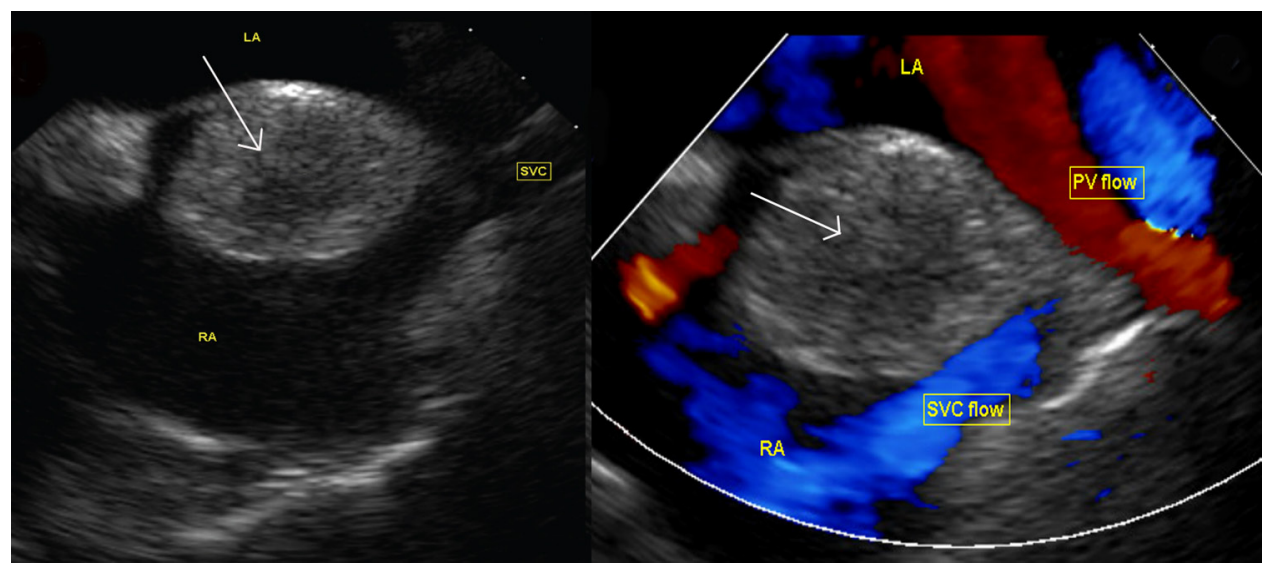

Figure 3 Transoesophageal echocardiography images of the heart showing lipomatous hypertrophy of interatrial septum (LHIS) in the left and relation of LHIS to pulmonary venous (PV) flow and superior vena caval (SVC) flow in the right.

\section{Learning points}

Multi-modality imaging including CT scan and TEE helped in diagnosing LHIS, which is a benign adipose tumour of the heart.

- Awareness of LHIS as a possible cause for focal atrial FDG uptake (due to presence of brown fat) is important for healthcare providers to prevent misdiagnosis and avoid invasive testing and/or treatment with chemotherapy and radiation.

\section{Competing interests None.}

Patient consent Obtained.

\section{REFERENCES}

1. Heyer CM, Kagel T, Lemburg SP, et al. Lipomatous hypertrophy of the interatrial septum: a prospective study of incidence, imaging findings, and clinical symptoms. Chest 2003;124:2068-73.

2. Fan CM, Fischman AJ, Kwek BH, et al. Lipomatous hypertrophy of the interatrial septum: increased uptake on FDG PET. AJR Am J Roentgenol 2005; 184:339-42.

3. Simons M, Cabin HS, Jaffe CC. Lipomatous hypertrophy of the atrial septum: diagnosis by combined echocardiography and computerized tomography. Am $J$ Cardiol 1984;54:465-6.

This pdf has been created automatically from the final edited text and images.

Copyright 2012 BMJ Publishing Group. All rights reserved. For permission to reuse any of this content visit http://group.bmj.com/group/rights-licensing/permissions.

BMJ Case Report Fellows may re-use this article for personal use and teaching without any further permission.

Please cite this article as follows (you will need to access the article online to obtain the date of publication).

Sawant AC, Srivatsa SS. Multi-modality imaging for accurate diagnosis of lipomatous hypertrophy of interatrial septum in a patient with lung cancer and increased FDG uptake on PET. BMJ Case Reports 2012;10.1136/bcr.03.2012.6074, Published XXX

Become a Fellow of BMJ Case Reports today and you can:

- Submit as many cases as you like

- Enjoy fast sympathetic peer review and rapid publication of accepted articles

- Access all the published articles

- Re-use any of the published material for personal use and teaching without further permission

For information on Institutional Fellowships contact consortiasales@bmjgroup.com

Visit casereports.bmj.com for more articles like this and to become a Fellow

Keep up to date with all published cases by signing up for an alert (all we need is your email address) http://casereports.bmj.com/cgi/alerts/etoc 